\title{
Microbial mat mediated structures in the Ediacaran Sonia Sandstone, Rajasthan, India, and their implications for proterozoic sedimentation
}

Subir Sarkar ${ }^{\mathrm{a}}$, Pradip K. Bose ${ }^{\mathrm{a}}$, Pradip Samanta ${ }^{\mathrm{a}}$, Pratip Sengupta ${ }^{\mathrm{a}}$ and Patrick G. Eriksson $^{\mathrm{b}}$

a Department of Geological Sciences, Jadavpur University, Kolkata 700 032, India

${ }^{b}$ Department of Geology, University of Pretoria, Pretoria 0002, South Africa

\section{Abstract}

A strong influence of microbial mats on the physics of Neoproterozoic sedimentation is explored within a 60 m-thick stratigraphic interval within the Sonia Sandstone, Jodhpur Group, western India. This marine interval is bounded by two terrestrial units, its base being marked by a transgressive lag and the top by an unconformity. Progradation from upper neritic, above fair-weather wave base to supralittoral settings was later terminated by a transgression; deposits of lower shoreface-upper shoreface transition thus overlie supralittoral aeolian sandstones, the basal contact of the former deposits being marked by another transgressive lag.

A wide spectrum and abundant examples of microbial mat or mat-derived structures supports unusual cohesiveness within granular sand deposited in a high-energy marine environment. The cohesiveness is manifested in abundant preservation of several delicate primary structures and also in their replication in overlying beds, even after they were subjected to high-energy currents.

A low rate of sedimentation and severely restricted sediment reworking resulted from prolific mat growth, and consequent depletion in the sediment budget was manifested in 
bedform migration and evolution. These factors could also have influenced the sequencebuilding pattern in a distinctive way, as is already reported from several Meso- and Neoproterozoic successions. Ubiquitous mat growth thus had the potential to impart significant distinctions to Proterozoic clastic sedimentary successions.

\section{Article Outline}

1. Introduction

2. Geological background

3. Depositional palaeoenvironment of the medial, marine Sonia Sandstone

4. Mat-related structures

4.1. ML (mat-layer) structures

4.1.1. mld (mat-layer discoidal) structure

4.1.2. mlc (mat-layer crumpled) structures

4.1.3. mlw (mat-layer wrinkled) structure

4.1.4. Interpretation

4.2. MI (Mat-induced) structures

4.2.1. misc (mat-induced surface cracks)

4.2.2. micr (mat-induced cracks along ripple crests)

4.2.3. misr (mat-induced surface ridges)

4.2.4. mib (mat-induced bulges)

4.2.5. Interpretation

4.3. MP (mat-protected) structures

4.3.1. mpsf (mat-protected setulf)

4.3.2. mppr (mat-protected patchy ripples)

4.3.3. mpr (mat-protected ripples)

4.3.4. Interpretation

5. Discussion: Possible implications of microbial mats for Proterozoic sedimentation processes and the sedimentary record

6. Conclusions

Acknowledgements

References 


\section{Introduction}

In this paper we address the application of biosedimentology (i.e., sedimentology in the context of ambient biosphere) to late Proterozoic sandy depositional systems. The influence of microbial mats on preserved clastic sedimentary structures, and in producing a host of more direct mat-related features in clastic sedimentary rocks is a growing field of investigation in Precambrian sedimentary studies (e.g., [Hagadorn et al., 1999], [Schieber, 1999], [Schieber, 2004], [Pflüger, 1999], [Gehling, 1999], [Noffke et al., 2001], [Noffke et al., 2006], [Parizot et al., 2005] and [Schieber et al., 2007]). Despite the lack of skeletal organisms, the contemporary biota, mostly unicellular, had the potential to influence the physics of Proterozoic clastic sedimentation, albeit in a way rather unfamiliar in a Phanerozoic context ([Seilacher and Pflüger, 1994], [Gehling, 1999], [Bottjer et al., 2000], [Eriksson et al., 2000], [Fischer et al., 2000] and [Sarkar et al., 2005]). Microbiota appeared on Earth before 3.8 Ma, and probably inhabited hot spring environments in many greenstone belts (e.g., Reysenbach and Cady, 2001); they likely flourished during Meso-Neoproterozoic time (Schopf, 1999). Subsequently, they became virtually confined to stressful environments (e.g., highly saline settings such as the modern Shark Bay, Australia), where conditions were too harsh for most other organisms, particularly grazing invertebrates ([Hagadorn and Bottjer, 1999], [Schieber, 1999] and [Schieber, 2004]).

Microbial mats and the range of structures they leave behind in the modern clastic sedimentary record are well known (e.g., Gerdes et al., 1985); however, it is the almost ubiquitous occurrence of such mat-related features which serves to distinguish many Proterozoic (and presumably Archaean as well, see Noffke et al., 2006) clastic settings and their records from those of the Phanerozoic. Microbiota lend cohesiveness to clastic sediments, especially sand and reduce its erodibility ([Schieber, 1998], [Schieber, 1999], [Schieber, 2004], [Gehling, 1999], [Pflüger, 1999], [Gerdes et al., 2000], [Noffke et al., 2001], [Noffke et al., 2002], [Noffke et al., 2003], [Sarkar et al., 2004], [Sarkar et al., 2005] and [Sarkar et al., 2006]); this influence must have been commonplace across many environmental boundaries during the Proterozoic. Primary bed-surface structures, even those with little preservation potential, are thus likely to be very well preserved in 
Proterozoic sandstone formations. Also, various physical forces acting on microbial mats can generate a host of penecontemporaneous sedimentary structures in sandstones (e.g., [Pflüger and Gresse, 1996] and [Simonson and Carney, 1999]; for a recent review, see [Schieber, 2004] and [Sarkar et al., 2006]). Although the microbial mats and microbiota themselves are only very rarely preserved in siliciclastic rocks ([Schieber, 1998] and [Schieber, 2004]), the preferred abundance of mat-induced structures and the abundant preservation of delicate primary sedimentary structures, notwithstanding high depositional energy, may impart a distinctiveness to sandstones of the Proterozoic time vis-a-vis the Phanerozoic. Prolific and widespread mat growth, a significant intrabasinal factor, may thus have had the potential to control, at least partially, the basic tenets of Proterozoic siliciclastic depositional systems. In order to investigate the potential of microbial mats to influence Proterozoic siliciclastic depositional systems, this paper focuses upon a coastal marine succession sandwiched between two terrestrial intervals in the Ediacaran Sonia Sandstone, Jodhpur Group, Rajasthan, India (Chauhan, 1999; Fig. 1a). After a brief introduction to the palaeoenvironment-related facies framework, the paper describes a spectacular range of inferred mat-related sedimentary structures preserved within the Sonia Sandstones, in order to add to the current knowledge of these features. Extant classification schemes of mat-related structures in clastic sediments are largely based on their genesis, and the two current main systems in use have inherent differences of opinion (Schieber, 2004). We here adopt a classification scheme, which strives to understand the genesis of these mat-influenced sedimentary structures in relation to their clastic depositional palaeoenvironment rather than just the detailed processes responsible for their formation. The final aim of this paper is to debate which basic characteristics this intrabasinal factor of the non-uniformitarian extent of mat growth might have imparted to Proterozoic siliciclastic depositional systems in general, and how it may have affected their preserved architecture. 


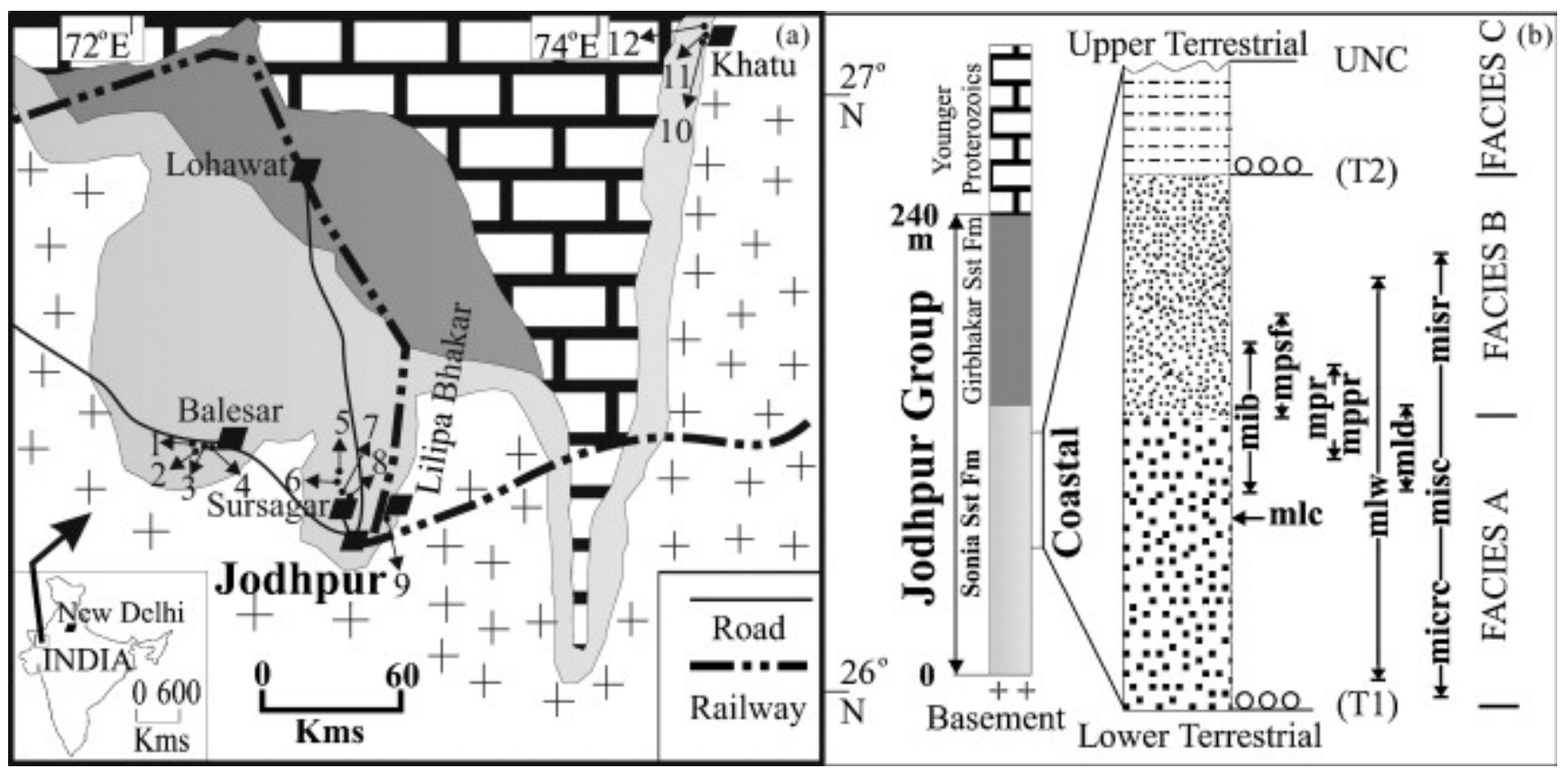

Fig. 1. Geological background of studied coastal segment of Sonia Sandstone Formation, Jodhpur Group (based on Sarkar et al., 2005): (a) outcrop map showing distribution of Sonia Sandstone and associated formations. Numbers indicate locations of sections used in Fig. 2. (b) Stratigraphic context of the coastal segment of the Jodhpur Group, in vertical section, built up moving in a downdip direction from Jodhpur city. Distribution of different categories of mat-related features within the coastal facies succession is indicated on the right.

\section{Geological background}

The $\sim 150$ m thick mud-poor Sonia Sandstone Formation at the base of the Jodhpur Group is thought to be 600 Ma old, Ediacaran (Knoll et al., 2004), on the basis of radiometric dating of acid volcanic rocks ([Rathore et al., 1996], [Rathore et al., 1998] and [Paliwal, 1998]) that immediately underlie and also interfinger with the formation (Paliwal, 1998). The undated mud-enriched Girbhakar Sandstone overlies it. The two formations together make up the Jodhpur Group (Fig. 1a and b). All through the Jodhpur Group, beds dip NW and there is little evidence of deformation except for broad warps (Pareek, 1981). Chauhan (1999) suggested deposition in an intracratonic rift or sag basin; the existence of a huge pile of rhyolite and acid tuff below the Sonia Formation and the 
nature of the sedimentary rocks must have influenced his conclusion, although he made no effective correlation between such data and his models.

The Sonia Sandstone is divisible into three tiers (Fig. 1b). The sandstones within the lower and upper tiers are coarser grained, even pebbly at places, have moderate to poor grain sorting, moderate (less than 15\%) matrix content, and are sublitharenites with incorporation of clasts of acid tuff. They are characterized internally by trough crossstrata and their depositional environment is presumed to have been fluvial in general (Chauhan, 1999).

In between these two intervals of dominant fluvial origin, the middle tier comprises wellsorted sandstone of mean grain-size about Ø1.27. Grains constituting the sandstone commonly bear ferruginous rims and unlike those in the lower and upper tiers, are well rounded. Planar laminae and tabular cross- strata characterize the sandstone in the middle tier internally and wave ripples are present frequently on bed surfaces. Petrographically, this tier is generally quartz arenite. Chauhan (1999) and Roy and Jakhar (2002) interpreted the palaeoenvironment of deposition as a beach, although facies analysis (Table 1) reveals a wider inferred palaeoenvironment within the coastal zone. The base of this interval is defined by a planar, sheet-like granular transgressive lag and its top is truncated by an unconformity, overlain by a conglomerate or pebbly sandstone of the upper fluvial unit, both the bounding levels being traceable all through the studied area (Fig. 2). Despite erosion at its upper contact, the medial, marine part of the Sonia Formation has an overall tabular geometry, with thickness varying from 40 to $60 \mathrm{~m}$. 
Table 1.

Description and interpretation of facies identified within the marine interval of the Sonia Sandstone

\begin{tabular}{|c|c|c|}
\hline Facies & Description & Interpretation (Fig. 3) \\
\hline $\begin{array}{l}\text { Upper } \\
\text { facies, C } \\
\text { (>25 m } \\
\text { thick) }\end{array}$ & $\begin{array}{l}\text { Relatively less sorted and still } \\
\text { coarser grained (MdØ } \varnothing 0.8 \text { ) } \\
\text { sandstone separated from the } \\
\text { underlying facies B by a laterally } \\
\text { persistent granular lag (Fig. 2). It is } \\
\text { characterized by large-scale, } \\
\text { normally graded cross-strata. Two } \\
\text { laterally equivalent subfacies, } \mathrm{C}_{1} \text { and } \\
\mathrm{C}_{2} \text { can be distinguished. } \mathrm{C}_{1} \text { is } \\
\text { widespread in occurrence, and is } \\
\text { characterized by } 1.8-2 \text { m-thick } \\
\text { cosets of troughs separated by } 2- \\
3 \text { cm thick wave rippled sheets of } \\
\text { relatively fine-grained sandstone. } \\
\text { The trough cross-strata orientation is } \\
\text { unimodal, northwestward (Fig. } 2 \text { ), } \\
\text { while that of the associated wave } \\
\text { ripples is polymodal. Subfacies } \mathrm{C}_{2} \text { is } \\
\text { characterized by a chevron-like } \\
\text { criss-cross arrangement of tabular } \\
\text { cross-strata in } 60-85 \text { cm thick co- } \\
\text { sets, terminated by a laterally } \\
\text { discontinuous wavy based, wave } \\
\text { winnowed lag of very well sorted } \\
\text { and abraded granules, closely } \\
\text { matching the coarsest fraction of } \\
\text { best developed in the same quarry }\end{array}$ & $\begin{array}{l}\text { A perpetually wave agitated relatively } \\
\text { deeper neritic palaeogeography is } \\
\text { inferred. Coset-thickness of chevron } \\
\text { cross-sets indicates the water depth } \\
\text { had been sufficient to accommodate } \\
\text { vertically accreted bedforms } 1 \text { m or } \\
\text { more in height, possibly at the very } \\
\text { shallow neritic environment } \\
\text { encompassing upper and lower } \\
\text { shoreface slope break, that could have } \\
\text { trapped the relatively coarse grain } \\
\text { fraction. The granular lag at the base } \\
\text { of the facies unit corroborates a } \\
\text { transgression on top of a supralittoral } \\
\text { deposit. The vertically accreted } \\
\text { bedforms might have acted as barriers } \\
\text { that led to local enhancement of the } \\
\text { tide, as indicated in subfacies A } 2 \text { The } \\
\text { coarsening- and thickening- upward } \\
\text { trends indicate a progradational } \\
\text { character in this facies also. }\end{array}$ \\
\hline
\end{tabular}




\begin{tabular}{|c|c|c|}
\hline Facies & Description & Interpretation (Fig. 3) \\
\hline & where subfacies $A_{2}$ occurs (Fig. 2). & \\
\hline $\begin{array}{l}\text { Middle } \\
\text { facies, B } \\
\text { (28 m } \\
\text { thick) }\end{array}$ & $\begin{array}{l}\text { Well sorted sandstone perceptibly } \\
\text { coarser than facies A (MdØ } \sim 1.5 \text { ) } \\
\text { and distinguished by common } \\
\text { occurrence of aeolian features like } \\
\text { adhesion laminae, inversely graded } \\
\text { translatent strata, very low amplitude } \\
\text { impact ripples, regular alternations } \\
\text { of grain-flow and grain-fall strata in } \\
\text { large scale (20 cm thick) cross-sets } \\
\text { characterize this facies. Wave } \\
\text { rippled sheets in finer grained } \\
\text { sedimentary rocks intervene } \\
\text { intermittently at different levels. } \\
\text { Additionally, alternations between } \\
\text { planar laminae and wave ripples, } \\
\text { typical of facies A, are noticed in its } \\
\text { bottom-most part (0.5-1 m) where it } \\
\text { grades down into facies A. The } \\
\text { contact between the two facies has } \\
\text { been arbitrarily fixed by the first } \\
\text { appearance of well preserved rill } \\
\text { marks. Facies B is persistent all over } \\
\text { the studied area (Fig. } 2 \text { ). }\end{array}$ & $\begin{array}{l}\text { Abundance of aeolian features attests } \\
\text { to deposition largely within the } \\
\text { supralittoral zone. On the assumption } \\
\text { that rill marks were generated } \\
\text { preferably at the backshore-foreshore } \\
\text { transition, the thin basal segment } \\
\text { characterized by alternation between } \\
\text { wave rippled and planar laminated } \\
\text { sheets is inferred to be of high littoral } \\
\text { origin. The wave rippled sheets at the } \\
\text { upper level, when laterally bounded by } \\
\text { aeolian dune cross-sets, possibly } \\
\text { formed in interdune areas, but those } \\
\text { traced across a number of adjacent } \\
\text { quarries might be related to sea-level } \\
\text { rise, albeit at short time-scale, not } \\
\text { altering the palaeogeography } \\
\text { substantially. Facies B unit within } \\
\text { itself as well as the facies A-B } \\
\text { together are progradational. }\end{array}$ \\
\hline $\begin{array}{l}\text { Lower } \\
\text { facies, A } \\
\text { (30 m) }\end{array}$ & $\begin{array}{l}\text { Coarse to medium grained (Md } \varnothing \\
\text { 1.7), well-sorted sandstone } \\
\text { characterized by repeated } \\
\text { alternations between sets of tabular } \\
\text { cross-strata and parting lineated } \\
\text { planar laminae, the latter dominating }\end{array}$ & $\begin{array}{l}\text { Very shallow neritic embodied by } \\
\text { upper shoreface to lower littoral, } \\
\text { encompassing wave-dominated high } \\
\text { energy beach, foreshore-like } \\
\text { environment mainly, although locally } \\
\text { tide intensity accentuated relatively }\end{array}$ \\
\hline
\end{tabular}




\begin{tabular}{|l|l|l|}
\hline Facies & Description & Interpretation (Fig. 3) \\
\hline $\begin{array}{l}\text { its top where washed out dunes and } \\
\text { wave ripples migrating along } \\
\text { troughs of larger ripples are } \\
\text { commonplace. In the lower part of } \\
\text { the facies unit, local occurrence of } \\
\text { mud drapes, also in pairs, on } \\
\text { foresets, and the herringbone cross- } \\
\text { bedding azimuth warrants distinction } \\
\text { of a subfacies A2; otherwise } \\
\text { downcurrent transformation of cross- } \\
\text { strata from tabular to plane beds and } \\
\text { facies unit is shoaling upward within } \\
\text { a unidirectional cross-bed azimuth is } \\
\text { typical (subfacies A1; Fig. 2). }\end{array}$ & \\
\hline
\end{tabular}

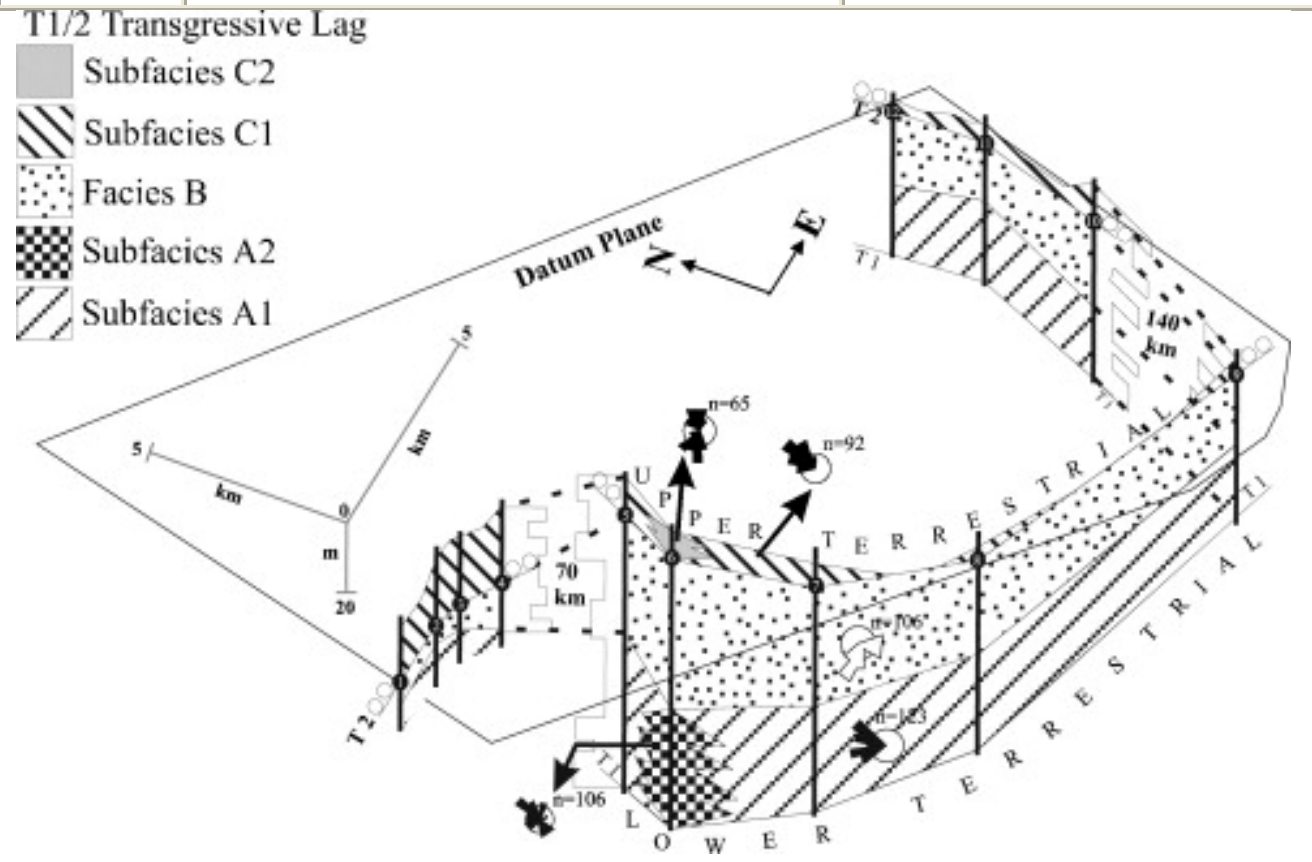

Fig. 2. Facies distribution and palaeocurrent data: Fence diagram based on facies correlation across the study area, using the younger transgressive lag (T2) as the datum 
plane (for locations of measured sections see Fig. 1). Palaeocurrents for each facies are given (marine, solid roses; aeolian, open rose).

\section{Depositional palaeoenvironment of the medial, marine Sonia Sandstone}

Relevant stratigraphic and sedimentological details were collected from 12 long vertical sections from relatively deeper quarries that are located, on infrastructural consideration, in three different regions of the topographically controlled arcuate outcrop belt of the Sonia Sandstone (Fig. 1a). A fence diagram correlating contacts between depositional facies in these sections reveals the stratigraphic and palaeoenvironmental framework of the Sonia Sandstone, notwithstanding the wide gap between clusters of the sections (Fig. 2). The rocks comprising the studied shallow marine interval (Fig. 1b) are very well laminated in the total absence of disruptive burrows, and spectacular preservation of bed surface structures makes them focal objects for the present investigation. Considering the strong wave and tide activity in their depositional palaeoenvironment such preservation, indeed, appears unexpected. The open-cast quarries offer an excellent opportunity to study the structures both in bed-normal and bed-parallel sections, as beds generally dip only gently.

Although the facies constituents of the middle interval of the Sonia Sandstone, superposed in a non-repetitive succession (see three-dimensional facies relationships in Fig. 2), have already been dealt with by Sarkar et al. (2005), a brief summary of the three identified facies (lower A, B and upper facies, C: Table 1) is deemed necessary here, also to support a later attempt to correlate mat-related features with palaeogeography (see also Fig. 1 and Fig. 3). 


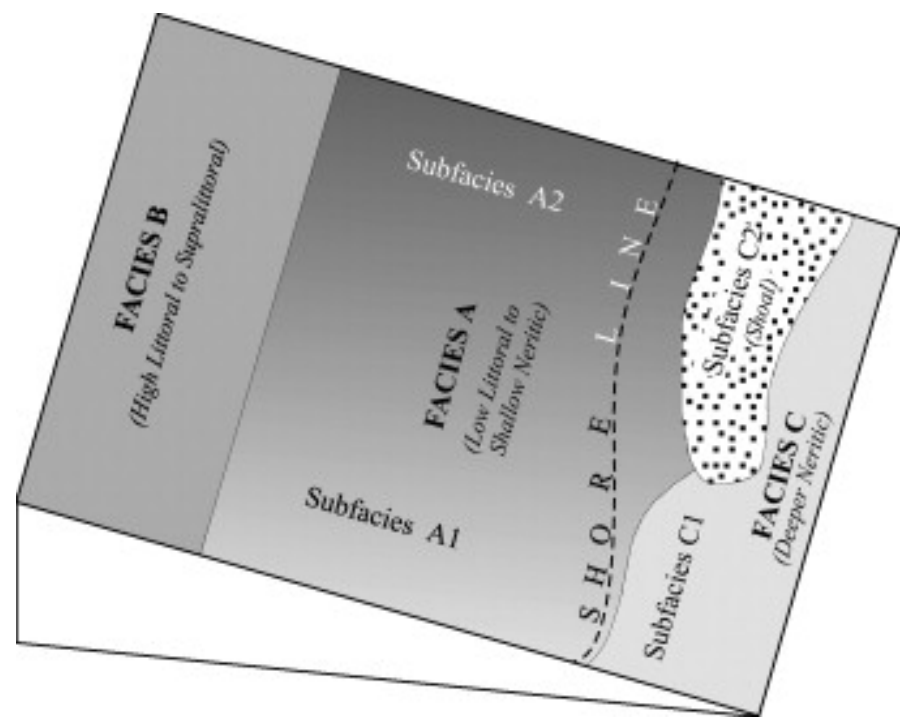

Fig. 3. Cartoon displaying inferred palaeoenvironmental (entirely above FWWB, Fair Weather Wave Base) distribution of the facies constituting the coastal segment of the Sonia Sandstone.

\section{Mat-related structures}

The microbial mat-related sedimentary structures described here are all bed-surface features, and bedding planes are adequately exposed only in facies A and B, since abundant occurrence of parting-lineated planar laminae makes them the natural choice of the miners cutting slabs for building purposes. The present search for microbial matrelated structures thus remained confined to these two facies, encompassing an inferred palaeoenvironment from the shallow neritic, well above the fair-weather wave base, to a supralittoral setting (Fig. 3). Despite difference in their paleoenvironment, albeit within a short range, the inferred mats have certain common petrographic hallmarks. Unlike the coarse and medium grained sandstones underlying, all of the mat layers are heavily enriched in ferruginous cement and distinctly finer, made of well sorted fine sand or silt. The silty layers are invariably rich in detrital mica, much larger in size than the associated quartz grains. Significantly, the mica flakes are very often random in orientation, inclined in a preferred direction or arranged in wavy-crinkly laminae (Fig. 4a-d), not consistent with simple vertical settling, imply trapping by microbial mat instead ('flypaper effect', [Gerdes and Krumbein, 1987], [Schieber, 1999] and [Schieber, 2004]). Prolific microbial mat growth in the Sonia Sandstone has, nonetheless, been recognized already (Schieber et 
al., 2007). The first detailed account of mat-related structures in the Sonia Sandstone is presented below under three different categories, based on a simple classification system: the latter discriminates whether the structures reflect preserved mat-layers (matgrounds), were induced by mats, or, thirdly, owe their preservation to mats. Their observed distribution within the stratigraphic column is summarized in Fig. 1b.
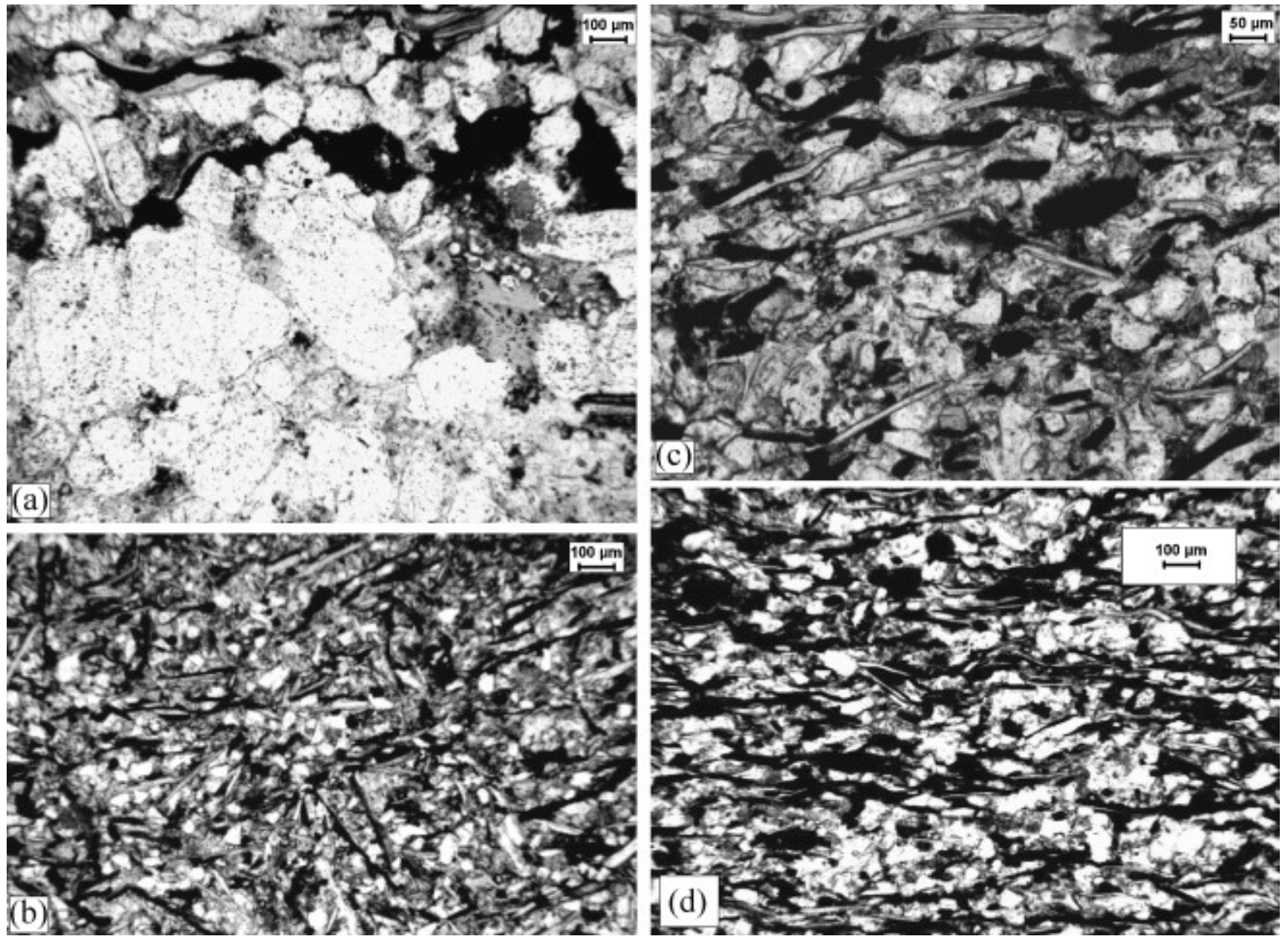

Fig. 4. Mat-layer on top of coarse to medium grained Sonia sandstones are distinctly finer grained, rich in ferruginous cement and detrital mica. The mica flakes may be arranged, more or less, bed-parallel (a, at top), randomly (b) in preferred inclination (c) or in wavycrinkly laminae (d). (All scale bars in this paper are $10 \mathrm{~cm}$ long, unless specified otherwise.) 


\subsection{ML (mat-layer) structures}

This category is for structures that are considered to be directly related to the microbial mat layer itself.

\subsection{1. mld (mat-layer discoidal) structure}

The generally reddish yellow colour of the sandstone acquires a darker hue within this structure that appears at first sight as a packed assemblage of stromatolites, which grew laterally, instead of vertically (Fig. 5a). It forms a thin sheet only about $2 \mathrm{~mm}$ thick and internally massive, and having a non-erosional base, which is planar on plane beds (Fig. 5b) and corrugated on wave-rippled surfaces. In plan, it comprises a cluster of discshaped bodies characterized by concentric rims, with a crenulated appearance resulting from their being made up of discrete small outward-convex spindles (Fig. 5a). These spindles show a tendency for mutual overlapping, but only locally. The cores of these discs are circular or oval in shape and are occupied by mutually interlinking small chiplike bodies having no definite geometry (Fig. 5a). The spindles are also not profoundly elongated immediately outside the core, but become so towards the periphery. Maximum length and width of the spindles measured is 12 and $1.2 \mathrm{~cm}$, respectively, and disc diameter is, on average, $30 \mathrm{~cm}$. As the spindles are slightly convex-upward in geometry, and their packaging being tight, the lateral contacts between adjacent spindles are generally hairline grooves, wider only between their tips (Fig. 5a). Locally, multiple spindles arise from a single point, initiating growth of new branches from the discs (Fig. 5a). The branches often wrap around the adjacent discs, filling the space between the discs (Fig. 5a). The contacts between adjacent discs thus appear irregular. Locally, strings of spindles with subdued tendency for concentric growth, fan out from the margins of such assemblages. The fan-axis maintains no definite relationship with crests of the wave ripples underlying these structures (Fig. 5c). This mld structure has been documented at four different stratigraphic levels, close to each other, and all confined to the top of facies A, transgressing marginally into facies B (Fig. 1b). 
openUP (April 2008)
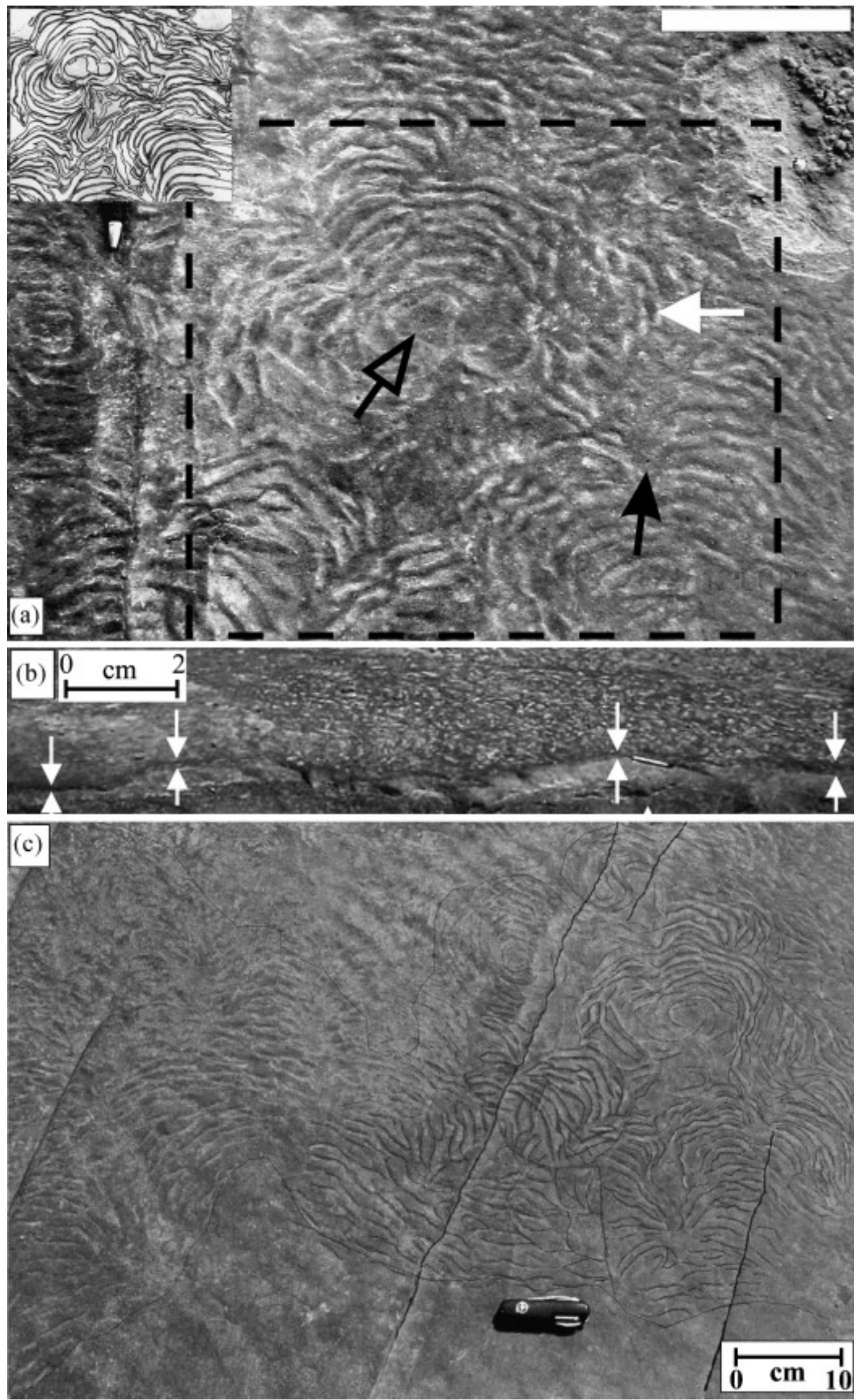
Fig. 5. (a) Plan view of laterally juxtaposed discoidal colonies. Note flat chips of irregular geometry at the centre (black open arrow) of individual colonies, spindles accreted around them, local branching (black solid arrow) and "compromising” boundaries between adjacent colonies (white arrow). Rectangle marked is sketched at top left. (b) Oblique view. Note thickness of the dark coloured sheet-likemld body (between two oppositely directed rows of arrows). Also note its flat base, while the vertical face of the outcrop is irregular. (c) Lateral expansion of an mld lump, apparently from left to right with a narrow zone in between. Where mat growth was inhibited, underlying ripples are exposed. Ignore four, more or less mutually parallel rock fractures running obliquely.

\subsection{2. mlc (mat-layer crumpled) structures}

This structure represents a submillimetre-thick sheet on top of wave-rippled sandstone, and underlying wave ripples are exposed only beyond its frayed preservational edges (Fig. 6a). The sheet is crumpled, showing horizontal drag folds in diverse orientations, without any relation to the underlying wave ripple crests. Vertical height of the folds and spacing between them are up to $7 \mathrm{~mm}$ and $12 \mathrm{~cm}$, respectively. At the tight hinges, the fold crests tend to be overhanging, even appearing to be crushed and smearing sand on the bed surface (Fig. 6a). About a millimetre beneath the sheet, a thin (less than one millimetre) dark lamina occurs, that fails to replicate the same crumpling (Fig. 6b). This mlc structure has been observed on only one bed, at a relatively lower stratigraphic level than the mld structures, within the top part of facies A. 


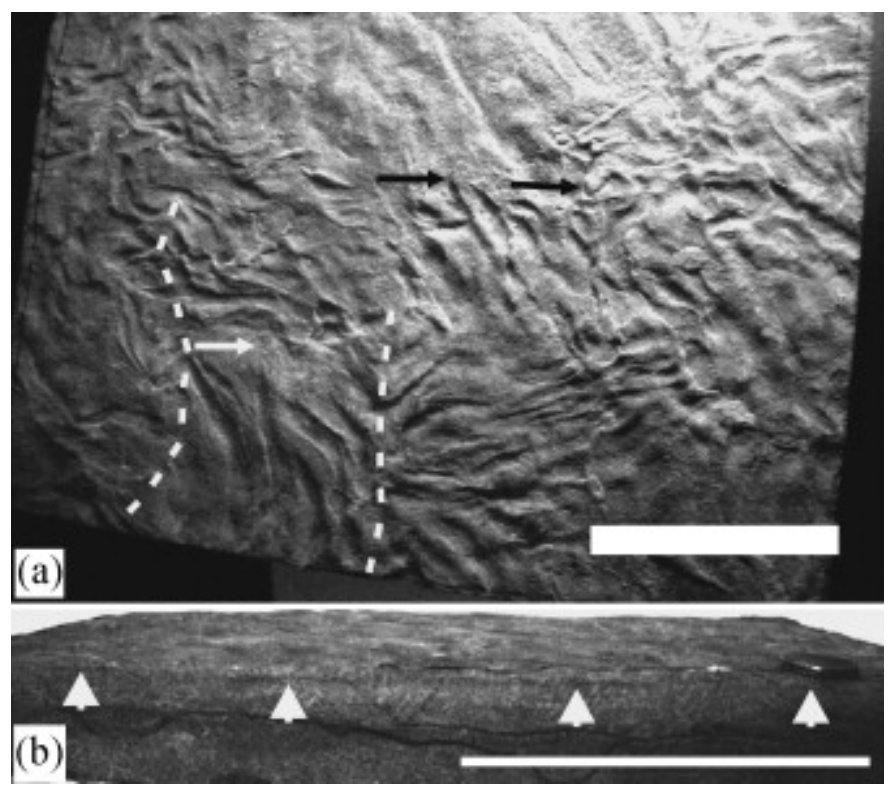

Fig. 6. (a) Plan view of mlc. Note drag folds (dashed lines), local smearing of sand at fold hinges (white arrow) and frayed edge of the torn sheet (black arrow). Also note that the underlying wave ripples are recognizable only where the sheet is removed (top right). (b) Oblique view of the bed covered by mlc. Note the black lamina of pyrite immediately underneath that does not show the same crumpling seen above.

\subsection{3. mlw (mat-layer wrinkled) structure}

Minute wrinkles on sub-millimetre-thick layers on top of sandstone bed surfaces are nearly ubiquitous in occurrence all through the facies A-B succession, especially from the base of the inferred marine succession to the mid-level of facies B (Fig. 1b). Immediately subjacent layers do not, however, replicate the same wrinkles. The marked differences in this structure compared to the mlc are in their far smaller dimensions and, straight or broadly curvilinear crests, comprising more or less parallel wrinkles (Fig. 7). Wrinkle height and spacing are, on average, 1.5 and $3 \mathrm{~mm}$, respectively. Wrinkle marks may be laterally continuous or discontinuous, being represented by close-set rows of minute spindle-shaped bodies. Wrinkle sets of diverse orientations may be superimposed one above the other. Wrinkles are generally strongly asymmetric in profile, with the steeper flank maintaining a similar broad orientation. 


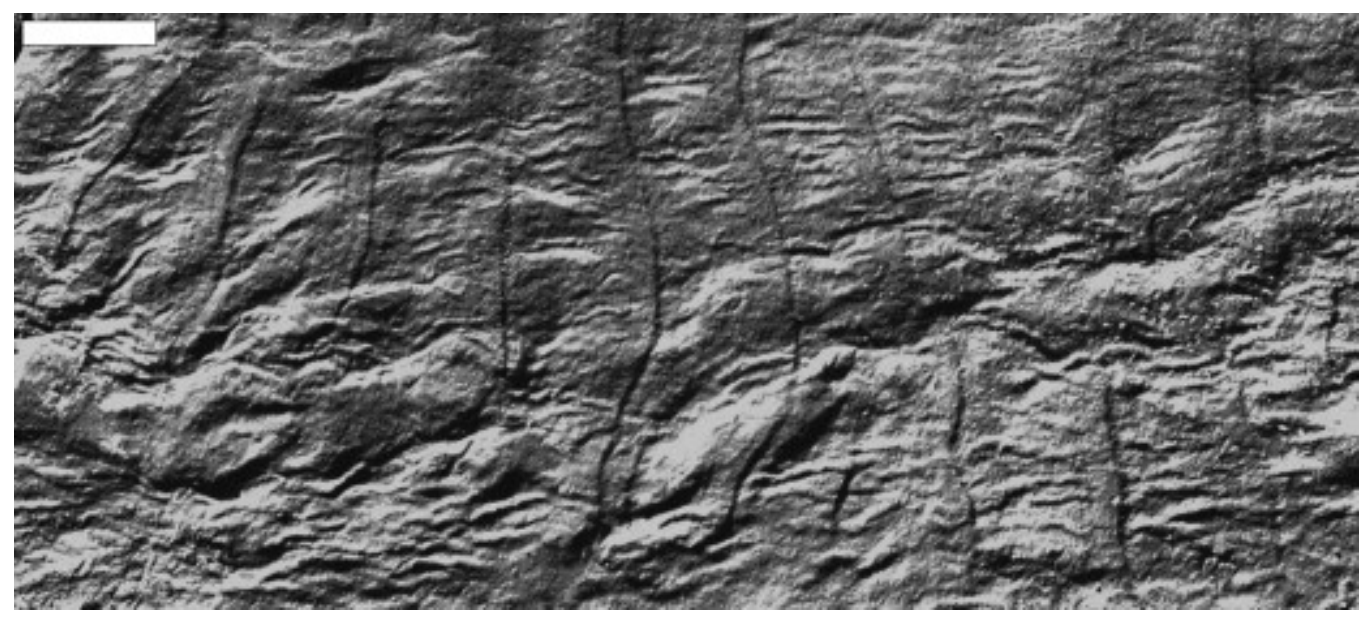

Fig. 7. mlw: Detached wave ripples on wrinkled sandy substratum preserved intact.

\subsubsection{Interpretation}

The irregularity in the form of branching, and the variation in shape, size and organization of smaller bodies within the otherwise regular pattern of the discs in the mld strongly favours biogenic growth. The mld in Fig. 5c having preferred growth direction may suggest biofabric responding to a slope-controlled flow of water as noted by Fouke et al. (2000), in a travertine deposit, although its total disregard to underlying ripple crests and troughs is disconcerting in this context. Radial growth and evident competition for space, tongue-like extension along narrow space available between two adjacent growth forms in Fig. 5a more strongly defies any such abiotic control (see the noise-free sketch). The thin layers on top of sandstone bed surfaces described above are considered as direct evidence for microbial mat layers or simply matgrounds. The fanning strings of spindles appear to reflect the tendency to extend the colony into new areas. The thin mld sandstone layers, with their bases conforming to the substratum geometry, and with their approximately uniform thicknesses, appear as simple drapes on the sand bed surface. The pattern of growth of the discs strongly suggests fractal growth of a microbiota colony, with smaller colonies fused together giving rise to larger colonies (cf. Seilacher, 1991). The colony acquired a flat shape, most probably, to facilitate photosynthesis. Convexupward tops of the spindle-like bodies, without corresponding undulation at their base, support a biogenic nature: either because of upward migration of microbiota in search of more light, or because of emission of gas from decomposed organic matter at the base and trapping of this at the top of a mat. Considering both the occurrence of wave ripples 
underneath, and their position in the stratigraphic column, it seems reasonable to assume that the mld structures developed in the littoral zone (Fig. 1b). The substantial thickness, of the mat layer mld ( $2 \mathrm{~mm}$ after compaction) suggests that a significant decline in depositional rate allowed the mat to grow thickly.

The mlc and $\mathbf{~ m l w}$ structures are recognizable only because the mat-bound sand layer was subjected to deformation. The submillimetre-thick layer, despite being made largely of well-sorted sand grains, behaved as a cohesive layer. The cohesion is attributable to extracellular polymeric substances from microbiota and to the grain-binding effect of microbial filaments (cf. Noffke et al., 2003). The pyrite layer immediately underneath the mlc (Fig. 6b) suggests that an anoxic condition developed underneath the mat by sulphurreducing bacteria (cf. [Bauld, 1981], [Gerdes et al., 1985] and [Schieber, 1999]). Lack of response of this pyritiferous layer to deformation of the mlc suggests that a shear plane was created above it when a horizontal stress was applied on top of the mlc layer, possibly by conflicting strong waves generated during a storm. The jagged margin of the mlc indicates that a large part of the mat was torn away by the waves. Whatever material was deposited during the storm was perhaps reworked during the following fair-weather period, but the residual mat and its bound sand layer escaped this destruction.

Disappearance of ripple undulations where the mat is still present indicates a process that has been called "leveling" by Noffke et al. (2001). The mlc possibly formed in the low littoral or very shallow neritic zone, where wave-thrust could have been very high. The observed single occurrence of mlc is possibly due to the fact that detachment from the substratum, as is well demonstrated above, renders mats readily erodible.

Wrinkle structures on sandstone have been variously attributed to gentle wave action on mats (e.g., [Hagadorn and Bottjer, 1997] and [Bouougri and Porada, 2002]), loading pressure and dewatering of mats during burial (Noffke et al., 2003) and gas accumulation underneath a mat (Pflüger, 1999). Although it is difficult to choose one or another of these mechanisms to explain ancient wrinkle structures, the unidirectional asymmetry exhibited by many of the wrinkle structures in the Sonia Sandstone are best explained by 
the first model. Pertinently, wrinkle structures are often found at the sediment-water interface in modern tidal flats (Hagadorn and Bottjer, 1997). As the stratigraphic distribution suggests, there was not much palaeogeographic restriction on mlw formation within the coastal marine interval of the Sonia Sandstone Formation, except for the requirement of a wet or damp surface.

\subsection{MI (Mat-induced) structures}

This category includes structures that do not suggest discrete mat layers directly, but mats were presumably needed to induce them. Among many possible varieties of such structures, the following features have been observed within the coastal segment of the Sonia Sandstone.

\subsection{1. misc (mat-induced surface cracks)}

Rectangular, polygonal, meandering or circular cracks are common on sandstone bed surfaces almost throughout the facies A-B succession of the Sonia Sandstone (Fig. 8a). These cracks do not generally maintain any relation with bed surface primary structures. In the majority of cases the cracks cut across each other (Fig. 8a). 
openUP (April 2008)
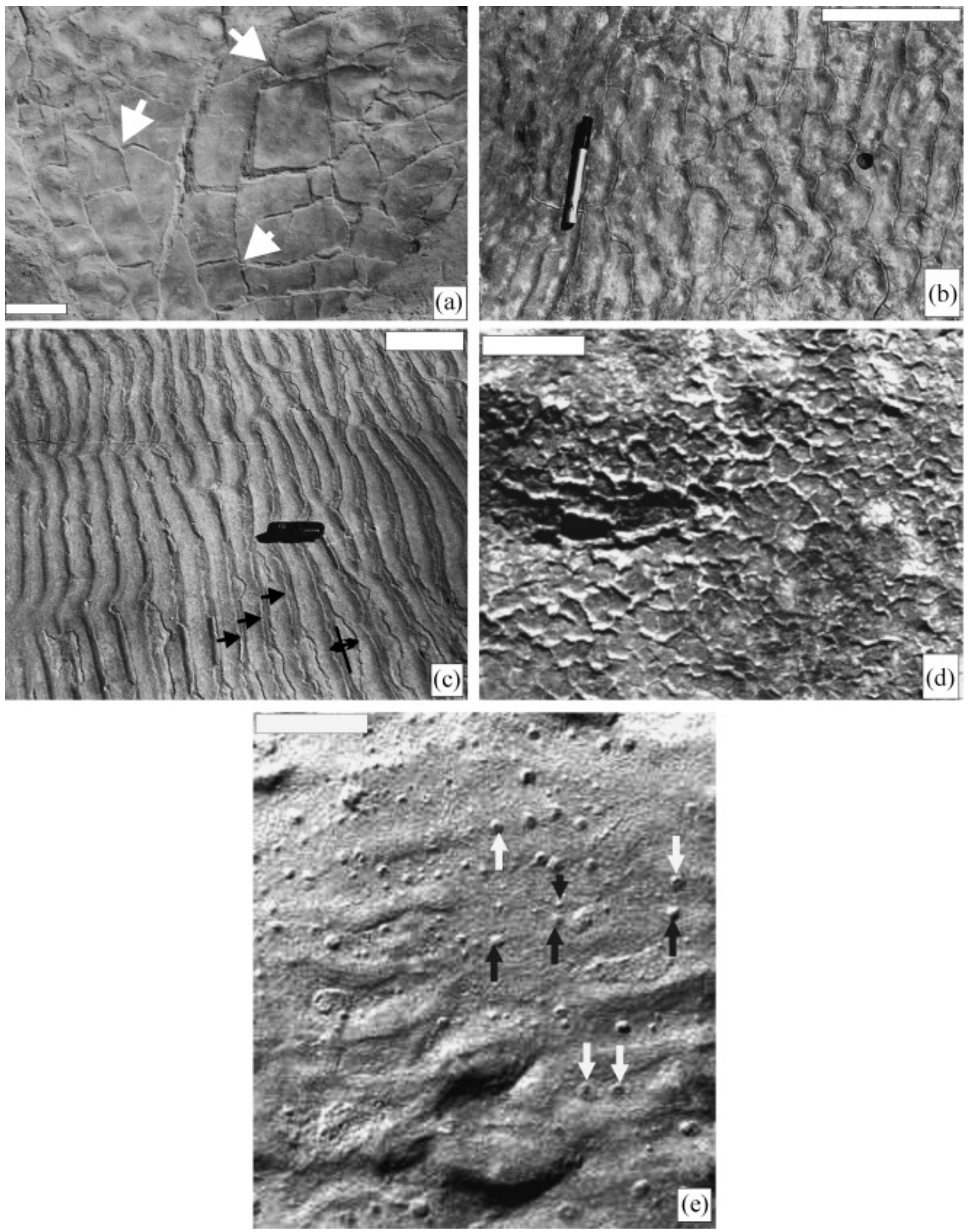
Fig. 8. misc, misr, micrc and mib: (a) rectangular to polygonal synaeresis cracks on sandstone bed surface (misc). Note that they cross-cut each other (arrows). (b) Cracks systematically following crests of wave ripples belonging to two different sets, which formed simultaneously (micrc). (c) Thin mat cover cracked along ripple crest (arrows at centre) and the mat then presumably gradually receded into the ripple troughs (double headed arrow on right) as desiccation proceeded. (d) Polygonal ridges on sandstone bed surface (misr). (e) Bulges, mib (black arrows) and sand volcanoes with crater-like depressions at their centers (white arrows) on sandstone bed with partially washed out ripples.

\subsection{2. micr (mat-induced cracks along ripple crests)}

In contrast to those described above, these cracks run along the crests of preserved wave ripples in sandstone devoid of mud. The cracks are less than a millimetre deep (Fig. 8b) and facilitated later, post-consolidation erosion of the thin mat from the ripple surface, still preserving rounded crests of the underlying wave ripples (Fig. 8c).

\subsection{3. misr (mat-induced surface ridges)}

Many of the sandstone bed surfaces bear linear, rectangular, polygonal and spindleshaped ridges (Fig. 8d); except for the parallel ones, they often cut across each other (Fig. 8d).

These cracks and ridges described above are found at different stratigraphic levels distributed almost throughout the facies A-B succession of the Sonia marine segment (Fig. 1b). However, they are absent in the inferred aeolian dune and translatent strata deposits.

\subsection{4. mib (mat-induced bulges)}

Little bulges, of variable diameters up to $3 \mathrm{~cm}$ and heights up to $7 \mathrm{~mm}$, often surrounded by minute ridges, are found on sandstone bed-surfaces (Fig. 8e). Flanks of the bulges are remarkably steep, up to $45^{\circ}$. Some of the bulges on the same bed surface have small crater-like depressions, defined by slightly raised rims at their centres (Fig. 8e). mib was 
observed at different levels in the upper part of facies A and the lower part of facies B (Fig. 1b).

\subsubsection{Interpretation}

Sand being essentially granular and non-cohesive, a microbial mat influence has been envisaged for the generation of the cracks observed on the upper surfaces of beds of wellsorted sandstone in the Sonia marine beds (cf. [Schieber, 1998], [Schieber, 2004], [Bouougri and Porada, 2002], [Sarkar et al., 2004] and [Sarkar et al., 2006]). Cracks of desiccation origin on mat-bound sand have been reported both from modern and ancient beds ([Schieber, 1998], [Schieber, 2004], [Pflüger, 1999], [Noffke et al., 2001] and [Bouougri and Porada, 2002]). Since many of the cracks in the Sonia Sandstone cross-cut each other, they are likely to be of subsurface synaeresis origin. Otherwise, in complete polygonal, rectangular or circular form, the cracks are equivocal about desiccation or synaeresis ([Reineck and Singh, 1980], [Allen, 1985] and [Astin and Rogers, 1991]). The spindle-shaped ridges possibly developed as the sand, made cohesive by a mat on top of it (which was cracked) flowed due to subsurface confining pressure, this closed the crack gradually; the crack-fill sand derived from overlying bed curled up at their sides. The existence of median furrows within many of these ridges developed where the two opposite tips of the curl tended to meet together. The curled mass now appears as a spindle-shaped round-bottomed ridge on exhumation. The cracks observed along ripple crests may represent desiccation of exposed mat-bound ripple crests leading to incipient tears in the mat-cover (cf. [Schieber, 2004] and [Sarkar et al., 2006]) or upward extrusion of sediment along the opening of desiccation cracks. However, selective occurrence of cracks along ripple crests without any tendency to acquire polygonal forms, supports an alternative subsurface synaeresis origin of these cracks because of stress accentuation on bedform highs. Possible thinning of mat cover on ripple crests could have facilitated the process.

The convex-upward geometry of the little sand bulges with steep flanks is difficult to explain in terms of bedform generation by current action. Their close association with crater-like depressions resembling sand volcanoes suggests that they may have formed 
when sand filled the space created under a mat cover which had been elevated by fluid pressure (cf., [Gerdes et al., 1993] and [Sarkar et al., 2004]). The craters presumably formed where the mat was ruptured under fluid pressure. The inferred mat-induced (MI in our classification scheme) structures in general did not apparently have much palaeogeographic control within the coastal Sonia sands, but the littoral zone was probably relatively more congenial for formation of mib. A rising water table during flood tide and concomitant ascent of the air trapped within littoral sand possibly created the little bulges as well as the ruptured ones.

\subsection{MP (mat-protected) structures}

Structures within this category could have been generated independently of mats, but their preservation presumably required mat protection.

\subsection{1. mpsf (mat-protected setulf)}

These structures are present in swarms, exhibit positive relief, are elongated in form, distinctly steep at one end and flaring at the other, and are strongly unidirectional in orientation (Fig. 9a). Their orientation differs from that of associated asymmetric wavecurrent combined flow ripples, but matches the orientation of aeolian cross-strata (Fig. 2). They, therefore, resemble inverted flutes, and are reported from a modern beach and named aptly as setulf by Friedman and Sanders (1974). Similar features are also generated by differential erosion of rock surfaces exposed for long periods of time. Nonetheless, there is no doubt about the primary origin of the mpsf within the Sonia Sandstone, not only because the exposures are very fresh, but also because when bedding planes are prized open, they reveal the structures with their casts at the sole of the overlying beds. Their dimensions are, more or less, similar on the same bed surface, but differ widely between surfaces. Maximum length, width and height measured in this study are $4 \mathrm{~cm}, 1.5 \mathrm{~cm}, 4 \mathrm{~mm}$, respectively. At places setulfs are present in lateral transition to $\mathbf{~ m l w ~ ( F i g . ~ 9 b ) ~ a n d ~ a r e ~ a l s o ~ f o u n d ~ o v e r p r i n t e d ~ o n ~ m l d . ~ A l t h o u g h ~ o b s e r v e d ~ a t ~}$ different stratigraphic levels, this feature remains confined to facies B, especially its lower part (Fig. 1b). 

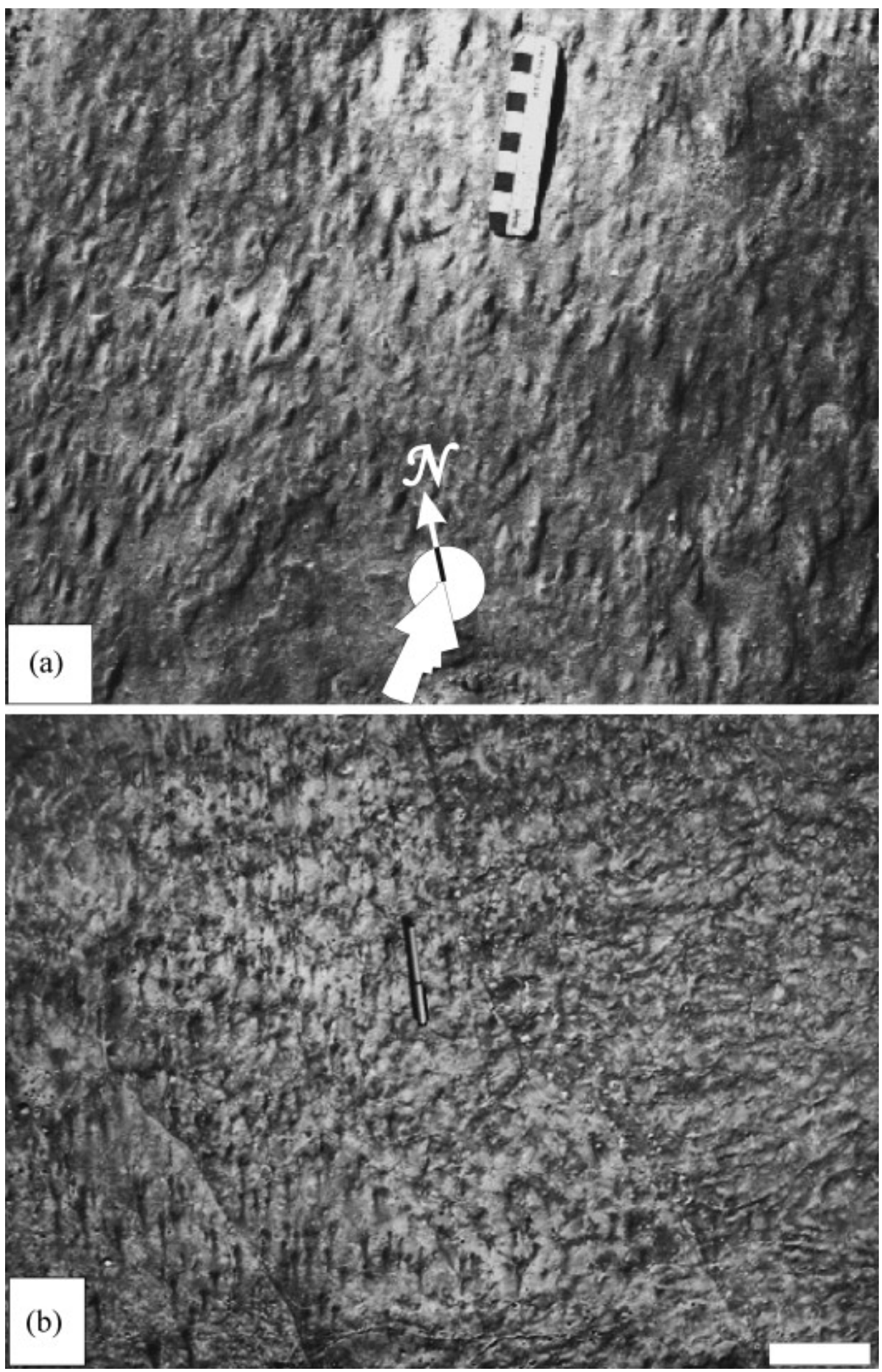
Fig. 9. (a) Swarms of setulf, mpsf. The rose indicates their orientation (compare with aeolian paleocurrent in Fig. 2). (b) Lateral transitions from wrinkle marks (on right and bottom) to setulf (on left).

\subsection{2. mppr (mat-protected patchy ripples)}

On many bedding plane surfaces, ripples with the same geometry and orientation are present in discrete patches (Fig. 10a). Peripheries of the rippled patches are sharp and on close observation appear jagged (Fig. 10a). The bed surface between such patches is generally smooth, planar and in some instances, parting-lineated. There are also rippled surfaces that have been reworked by a second generation of ripples, but only in isolated patches (Fig. 10b). The mppr are observed at different stratigraphic levels across the contact between facies A and B (Fig. 1b). 

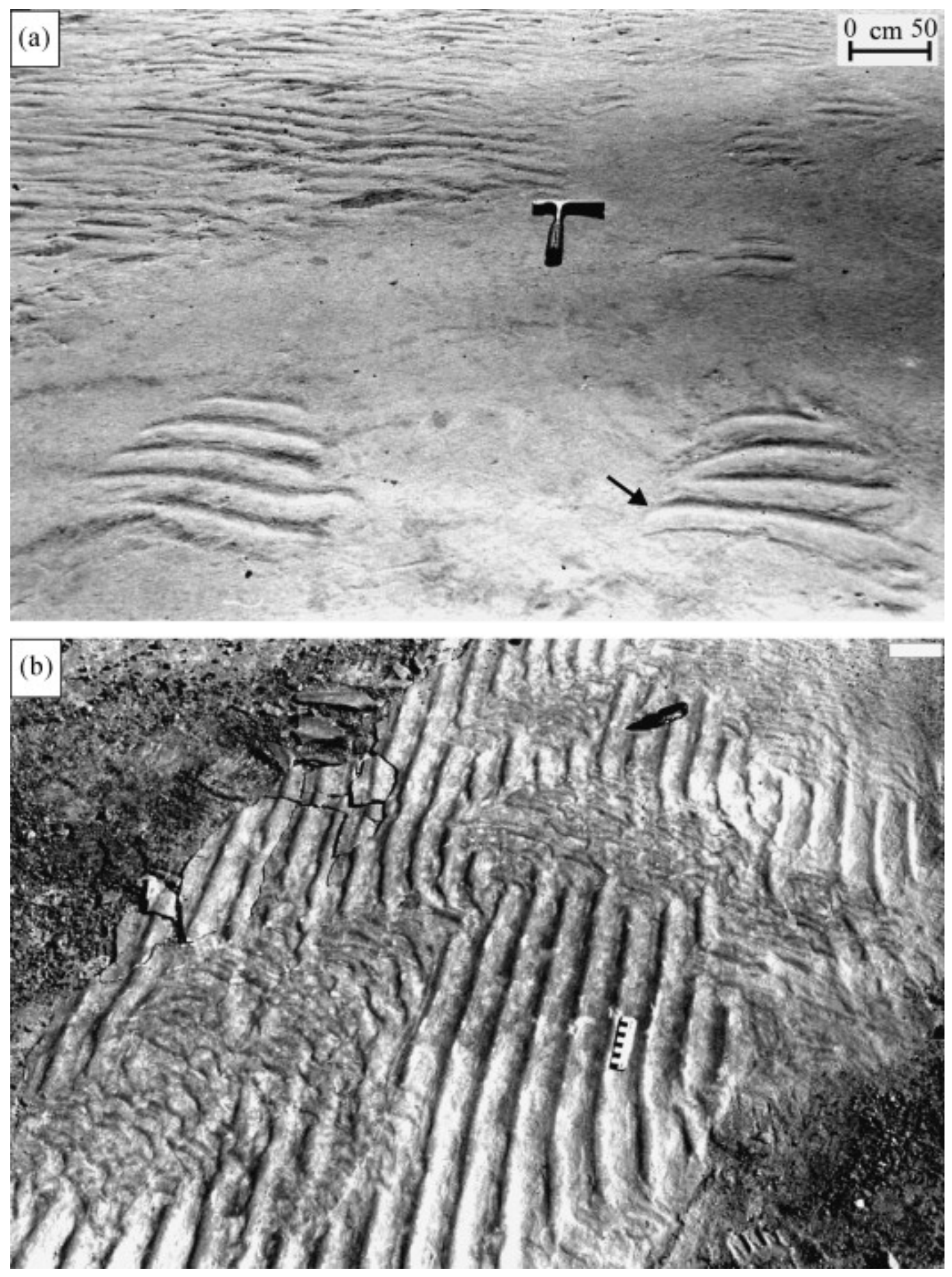

Fig. 10. Patchily preserved ripples, mppr: (a) Patchy retention of a ripple train after an erosional event. Note the jagged boundary of the ripple patches (arrow). (b) Patchy formations of a second-generation ripple system on the first generation ripple train. 


\subsection{3. mpr (mat-protected ripples)}

These are wave ripples, which are surprisingly well preserved immediately below beds characterized by large-scale cross-strata (Fig. 11a) or planar laminae (Fig. 11b). The ripples reveal broadly wavy erosional bases in sections normal to the ripple crests (that are rounded), and exhibit frequent bifurcation and less common internal chevron crosslaminae (cf. De Raaf et al., 1977). There is no mud in between the rippled surface and the overlying cross-beds. In certain instances, ripples on top of a very thin sandstone bed can be traced into the immediately underlying bed (Fig. 11c). 
openUP (April 2008)
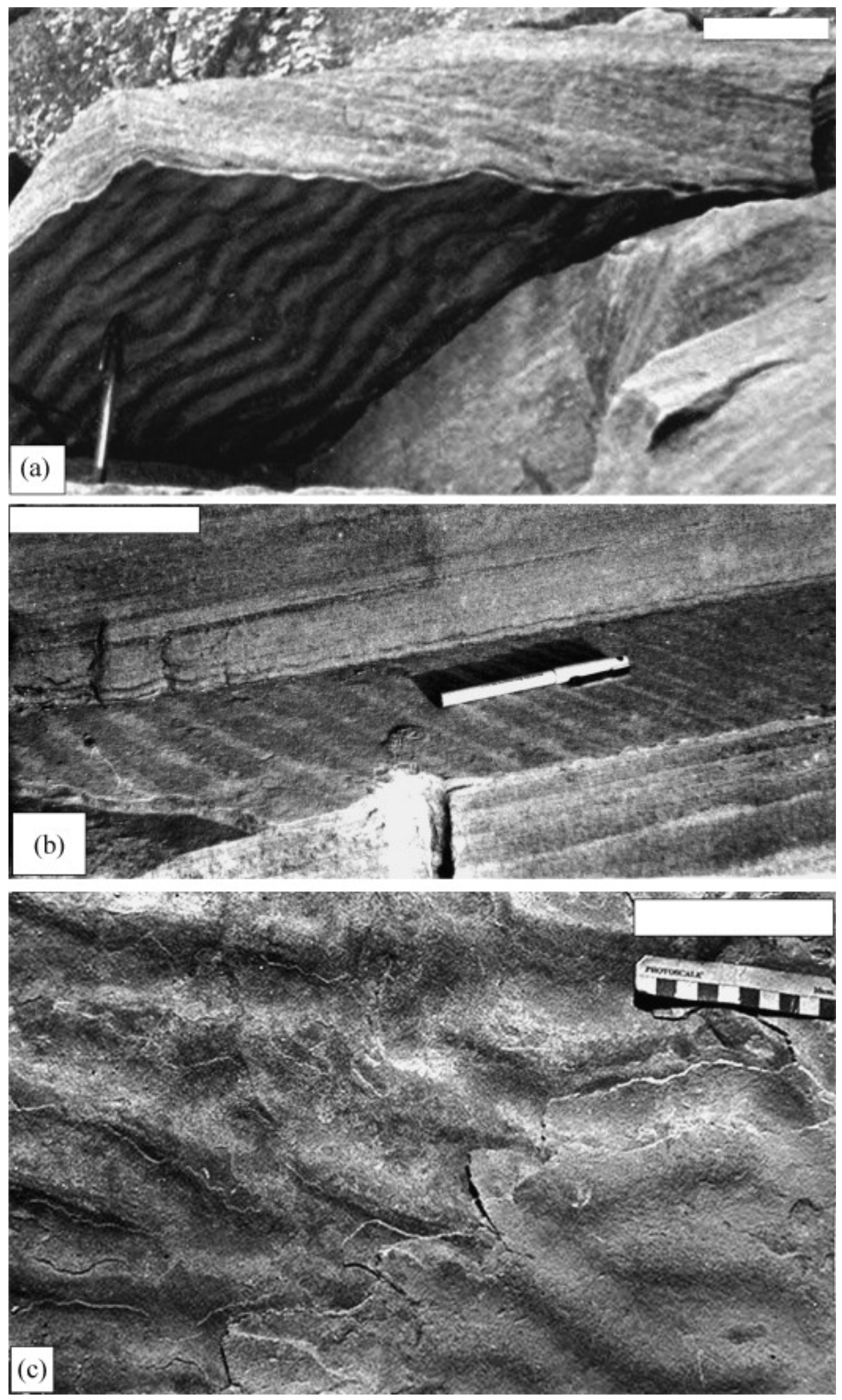
Fig. 11. Protected ripples, mpr: (a) ripple cast preserved intact at the sole of crossstratified sandstone. Note complete absence of mud between the two vertically juxtaposed sandstone beds. (b) Intact preservation of ripples under a planar laminated sandstone bed, a high flow regime product. (c) The thin youngest bed (bottom right) presents perfect moulds of the ripples on the bed underlying it (with little tendency for "levelling”). Note absence of mud on the original ripples, even within the troughs between them.

\subsubsection{Interpretation}

The preservation potential of setulf structures in a high-energy environment, like a beach, must be very poor because of their positive relief; they are, as far as we are aware, known only from modern beach environments (cf., Friedman and Sanders, 1974), and have not yet been reported from the rock record. In facies B, inferred to reflect a high littoral and supralitttoral setting in the Sonia Sandstone palaeoenvironment, mpsf are, nonetheless, present in profusion. In the modern backshore area of Chandipore beach, Orissa, India, setulfs are currently being generated by wind-deflated sand accumulating on the leeward side of pseudofeccal pellets (Fig. 12). The mpsf orientation parallel to that of associated aeolian cross-strata in the Ediacaran Sonia Sandstone (compare roses in Fig. 9a and 2) suggests a similar origin for these ancient setulfs, but presumably without involving pseudofecal pellets or shells obstructing the air flow. Erosional remnants of microbial mats or mat fragments could have provided such an obstruction. Hence the mpsf structures in the Sonia Sandstone may, indeed, be mat-derived, but preservation of these delicate positive structures in such profusion almost certainly calls for microbial mats contributing sufficient cohesion to the sand that originally formed them. Close association of some mpsf with $\mathbf{m l w}$ and $\mathbf{m l d}$ makes this postulate more credible. 


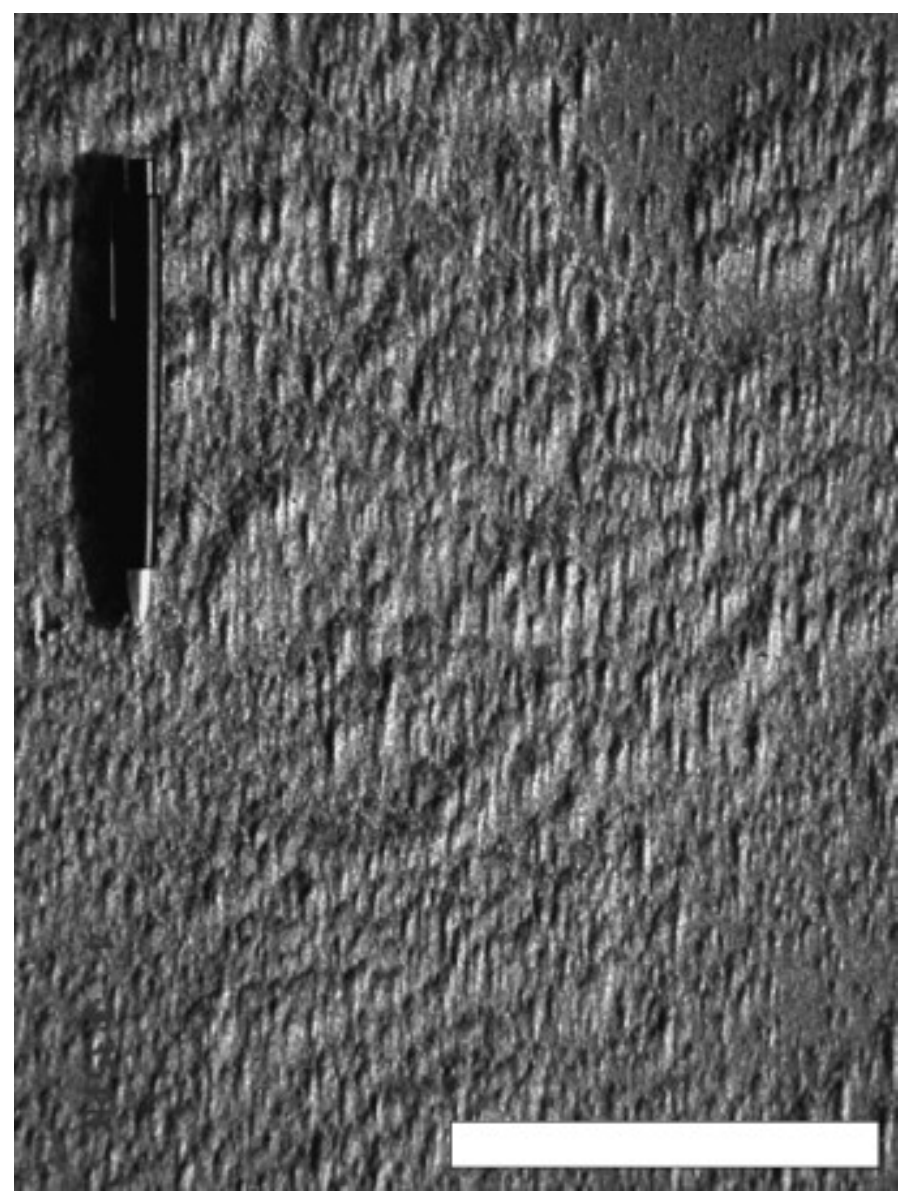

Fig. 12. Modern Setulf oriented parallel to the pen in Chandipore sea-shore. The ripple patches observed on bed surfaces (mppr) could have belonged to a single ripple train that was planed off in most parts of the exposed upper bed surface as the flow shear increased under later erosive shallow marine processes. Being random in distribution, not being arranged in rows, many of the rippled patches must have faced directly the sheet flow that planed off areas between them. This phenomenon can be explained readily by invoking sediment reworking where the intensified flow tore away a mat cover growing on the rippled surface. Jagged margins of the rippled patches clearly support growth of such a mat cover in the period between occurrences of the two flows of different intensities, with localised preservation of mat fragments above the extant ripple patches. (Schieber, 1998) and (Schieber, 1999) stresses that ripple patches should be characterised by smooth transitions to surrounding smooth sandstone bed surfaces, interpreted as reflecting local erosion of a mat (and reworking to form ripples in the 
resultant hollows) responsible for the smooth sandstone bed surface which gets preserved. The jagged edges of the Sonia Sandstone ripple patches argue against such an interpretation in this specific case. In the other variety of mppr, secondary reworking of a wave ripple train in some of its parts by a wave with a different direction of propagation is apparent. The first generation ripple escaped later reworking in those parts where a protective mat could not be removed by the secondary wave regime. Intact preservation of a ripple form immediately beneath a high-energy depositional product (mpr), without even a mud film between them, also suggests growth of a microbial mat on the ripples. A ripple from an underlying bed, which is replicated on top of a succeeding sandstone bed is a palimpsest ripple in the true sense (e.g., [Pflüger and Sarkar, 1996] and [Schieber, 2004]) and suggests vertical suspension fall-out of sand on to a rippled surface. However, the case of patchy superimposition of a new set of ripples on the palimpsest ripples argues against suspension settling of sand and preservation of older ripple calls for binding of sand by microbial mat.

\section{Discussion: Possible implications of microbial mats for Proterozoic sedimentation processes and the sedimentary record}

The abundant inferred mat-related structures described in this paper clearly suggest frequent growth of microbial mats on sand-bed surfaces in the coastal setting, especially the littoral-supralittoral zone, within the Sonia Sandstone palaeoenvironment. The occurrence of suspected mat-related features on numerous bed-tops at different stratigraphic levels and mat thickness apparently up to $2 \mathrm{~cm}$ (after compaction; see mld, Section 5.1.1) imply that sedimentation occurred at an overall low rate, and that it was even punctuated by hiatuses when mats developed. This postulate is consistent with the interpretation of Sonia Sandstone deposition largely within the littoral-supralittoral zone, presented in this paper.

It is also imperative to stress that severe impedance of either erosion or sediment reworking because of prolific microbial mat growth affected bedform behaviour in more 
ways than just stalling their migration. Dynamic bedform behaviour depends essentially on sediment (in the present case, largely sand) concentration in the sediment-driving flow, in addition to flow velocity and sediment grain size (e.g., [Harms and Fahnstock, 1965], [Allen, 1985], [Best, 1996] and [Kocurek, 1996]). Sediment concentration, in turn, depends on sand supplied from outside and sand entrained from the floor of the depositional system itself. The severe restriction on sediment reworking imposed by microbial mat growth implies that bedform behaviour would be controlled almost solely by the rate of sediment supply from outside. A negative sediment budget would thus easily result. As a consequence, bedforms in a train are likely to become detached from each other, and reduced in size. Such a hypothetical situation is recorded in Fig. 7 where low amplitude ripples set apart from each other are observed to bury the underlying wrinkled sandy substratum at regular intervals. The preservation of the wrinkle marks (as seen in the Sonia Formation rock record), inferred as reflecting the presence of a microbial mat, evidently denied any significant contribution from the floor of the depositional system to sand concentration in the flow. It can be envisaged that in such a depositional scenario, bedform-climb would result only infrequently (Fig. 13). The almost ubiquitous occurrence of microbial mats, which can be considered as an intrabasinal factor, is thus considered to have generally favoured negative sediment budgets during Sonia sedimentation; analogously, this factor would have applied within many Proterozoic depositional palaeoenvironments, in general.

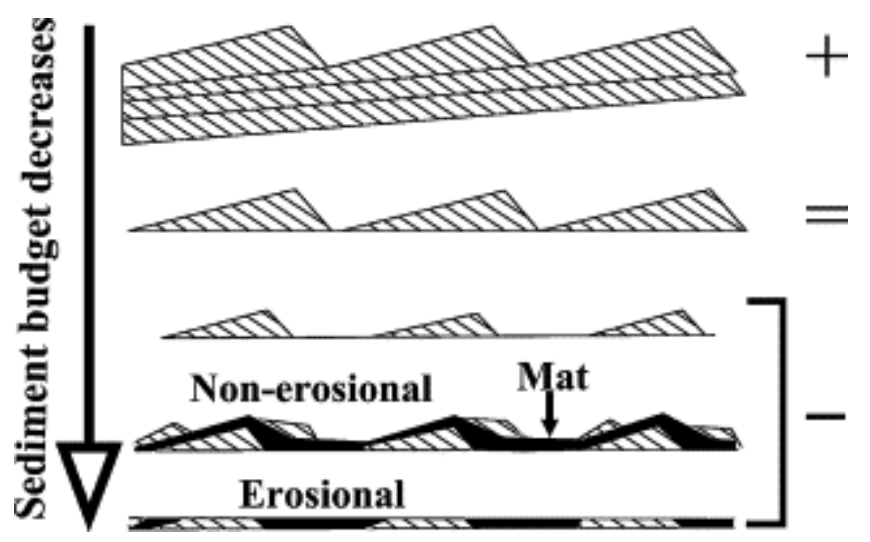

Fig. 13. Cartoon showing expected change in bedform behaviour with change in the sediment budget (=stands for equilibrium between sediment availability within and 
sediment output from the depositional system under consideration). (Modified from Kocurek, 1996).

Eriksson et al. (2000) record a similar association between depositional hiatuses, and the growth and reworking of microbial mats, but not within a littoral/supralittoral palaeoenvironment; these authors describe well- preserved roll-up mat fragments within the c.1.8 Ga Makgabeng palaeo-desert deposits, Waterberg Group, South Africa.

However, the high energy and viscous sediment-water mixtures to be expected from such (flash-flood) reworking of microbial mats did not lead to in situ preservation of any matrelated bed-surface features, unlike those in the marine Sonia Sandstone. Abundance of mat-related structures thus points to depletion of sediment budgets in highly disparate Proterozoic depositional settings. Additionally, mats reduced bedform migration rates, and led to evolution of smaller and more widely spaced sedimentary bedforms and their preservation in the Precambrian rock record.

Such an essentially "non-uniformitarian” (at least in the sense of frequency of occurrence of mats in the Proterozoic as compared to the younger record) mat influence on clastic sedimentation processes and products in the Proterozoic is not, however, limited to such smaller-scale features as discussed for the Sonia Formation. Sarkar et al. (2005) record a significant influence of microbial mats in forming amalgamated supralittoral storm beds along the coastal margins of the Neoproterozoic Vindhyan epeiric sea, in central India. An even larger scale effect of prolific Proterozoic mat growth is suggested by Sarkar et al. (2005), who describe vertical stacking of highstand systems tracts from clastic epeiric marine deposits of the Ediacaran Sonia Sandstone, Sirbu Shale and Upper Bhander Sandstone successions in India. These authors relate this sequence stratigraphic-scale feature to a combination of low epeiric seafloor gradients (leading to rapid transgressions) and overall limited sediment availability, largely attributed to mat growth. Banerjee and Jeevankumar (2005) also reported similar stacking of highstand systems tracts to the exclusion of transgressive systems tracts in the mat-infested Koldaha Shale, in the Palaeoproterozoic lower portion of the Vindhyan Supergroup. They highlighted abundance of mat-mediated wrinkle marks within subtidal deposits, in stark contrast to 
near-absence of such structures in modern subtidal settings owing to grazing (Browne et al., 2000). The concomitant flourishing of microbial mats and depleted sediment budgets may thus have had an important effect in modifying depositional processes and their preserved products within Proterozoic sedimentation systems, both in marine and terrestrial wet settings. We, therefore suggest here that microbial mat-induced factors should be given due consideration when studying ancient clastic sedimentary successions, especially those of Precambrian age. Not only that, the characteristics imparted by ubiquitous mat growth on sediment surfaces, as described for the Sonia Formation herein, and in many earlier papers by diverse authors, can be of immense help in planetary geology, detecting a record of life that did not progress beyond the very primitive stage (e.g., Westall et al., 2003).

\section{Conclusions}

The medial interval of the Ediacaran Sonia Sandstone, Jodhpur Group, Rajasthan, India, previously identified as a beach deposit, was laid down over a wider range of coastal palaeoenvironment, from the upper neritic transition to the supralittoral zone, as demonstrated in this paper. A large variety of microbial mat-related structures are found at different stratigraphic levels, almost all through this medial interval, especially across the shallow sublittoral-littoral-supralittoral transition. Some of the structures represent mat layers directly and others were either induced or preserved, or both, by living microbial mats. The stratigraphic distribution of a wide range of well preserved microbial mat-related features in the slowly prograding succession of the Sonia Sandstone suggests there may have been some palaeoenvironmental control on them.

Frequent mat growth, as demonstrated here for the Ediacaran Sonia Formation of India, indicates intermittent sedimentation and severely restricted sediment reworking. A negative sediment budget, significantly controlling bedform behaviour, therefore, was thus very likely the basic tenet of the Sonia or, in general, Proterozoic subaqueous siliciclastic depositional systems. We therefore suggest that studies of Precambrian and particularly the generally better preserved Proterozoic clastic sedimentary deposits should take the potential influence of microbial mats into account. All these characteristics 
imparted by ubiquitous microbial mat growth have a great potential in the study of

planets where rudimentary life might have existed, such as are currently being undertaken on Mars.

\section{References}

Allen, 1985 J.R.L. Allen, Principles of Physical Sedimentology, Allen and Unwin, London (1985) p. 272.

Astin and Rogers, 1991 T.R. Astin and D.A. Rogers, Subaqueous shrinkage cracks' in the Devonian of Scotland reinterpreted, J. Sed. Petrol. 61 (1991), pp. 850-859.

Banerjee and Jeevankumar, 2005 S. Banerjee and S. Jeevankumar, Microbially originated wrinkle structures on sandstones and their stratigraphic context: Paleoproterozoic Koldaha Shale, central India, Sed. Geol. 176 (2005), pp. 211-224.

Bauld, 1981 J. Bauld, Geobiological role of cyanobacterial mats in sedimentary environments: production and preservation of organic matter, BMR J. Austr. Geol. Geophys. 6 (1981), pp. 307-315.

Best, 1996 J.L. Best, The fluid dynamics of small scale alluvial bedforms. In: P.A. Carling and M. Dawson, Editors, Advances in Fluvial Dynamics and Stratigraphy, John Wiley and Sons (1996), pp. 67-125.

Bottjer et al., 2000 D.J. Bottjer, J.W. Hagadorn and S.Q. Dornbos, The Cambrian substrate revolution, GSA Today 10 (2000), pp. 1-7.

Bouougri and Porada, 2002 E. Bouougri and H. Porada, Mat related sedimentary structures in Neoproterozoic peritidal passive margin deposits of the West African Craton, Sed. Geol. 153 (2002), pp. 85-106. 
Browne et al., 2000 K.M. Browne, S. Golubic and L. Seong-Joo, Shallow Marine Microbial Carbonate Deposits. In: R.E. Riding and S.M. Awramik, Editors, Microbial Sediments, Springer-Verlag, Berlin, Heidelberg New York (2000), pp. 233-249.

Chauhan, 1999 D.S. Chauhan, Tectonic and sedimentary evolution of the Marwar basin: A Neoproterozoic-Early Cambrian intracratonic sag basin. In: P. Kataria, Editor, Proceedings of the Seminar on Geology of Rajasthan-Status and Perspective (A. B. Roy Felicitation Volume) Geology Department, MLSU, Udaipur (1999), pp. 111-125.

De Raaf et al., 1977 J.F.M. De Raaf, J.R. Boersma and A. Van Gelder, Wave-generated structures and sequences from a shallow marine succession, Lower Carboniferous, county Cork, Ireland, Sedimentology 24 (1977), pp. 451-483.

Eriksson et al., 2000 P.G. Eriksson, E.L. Simpson, K.A. Eriksson, A.J. Bumby, G.L. Steyn and S. Sarkar, Muddy roll-up structures in siliciclastic interdune beds of the Ca. 1.8 Ga Waterberg Group, South Africa, Palaios 15 (2000), pp. 177-183.

Fischer et al., 2000 H. Fischer, A. Sukhodolov, S. Wilczek and C. Engelhardt, Effects of flow dynamics and sediment movement on microbial activity in a lowland river, River Res. Appl. 19 (2000), pp. 473-482.

Fouke et al., 2000 B.W. Fouke, J.D. Farmer, D.J. Des Marais, L. Pratt, N.C. Sturchio, P.C. Burns and M.K. Discipulo, Depositional Facies and Aqueous-Solid Geochemistry of Travertine-Depositing Hot Springs (Angel Terrace, Mammoth Hot Springs, Yellowstone National Park, USA, J. Sed. Res. 70 (2000), pp. 565-585.

Friedman and Sanders, 1974 G.M. Friedman and J.E. Sanders, Positive-relief bedforms on modern tidal-flat that resemble molds of flutes and grooves: implications for geopetal criteria and for origin and classification of bedforms, J. Sed. Petrol. 44 (1974), pp. 181189. 
Gehling, 1999 J.G. Gehling, Microbial mats in the terminal Proterozoic siliciclastics: Ediacaran death masks, Palaios 14 (1999), pp. 40-57.

Gerdes et al., 1985 G. Gerdes, W.E. Krumbein and E.M. Holtkamp, Salinity and water activity related zonation of microbial communities and potential stromatolites of the Gavish Sabkha. In: G..M. Friedman and W.E. Krumbein, Editors, Hypersaline Ecosystems: The Gavish Sabkha Ecological Studies, Springer 53, Berlin, Heidelberg, New York (1985), pp. 238-266.

Gerdes and Krumbein, 1987 G. Gerdes and W.E. Krumbein, Biolaminated Deposits. Lecture Notes in Earth Sciences vol. 9, Springer-Verlag, New York (1987) p. 183.

Gerdes et al., 1993 G. Gerdes, M. Claes, K. Dunajtschik-Piewak, W.E. Krumbein and H.E. Reineck, Contribution of microbial mats to sedimentary surface structures, Facies 29 (1993), pp. 61-74.

Gerdes et al., 2000 G. Gerdes, T. Klenke and N. Noffke, Microbial signatures in peritidal siliciclastic sediments: a catalogue, Sedimentology 47 (2000), pp. 279-308.

Hagadorn and Bottjer, 1997 J.W. Hagadorn and D.J. Bottjer, Wrinkle structures: Microbially mediated sedimentary structures common in subtidal siliciclastic settings at the Proterozoic-Phanerozoic transition, Geology 25 (1997), pp. 1047-1050.

Hagadorn and Bottjer, 1999 J.W. Hagadorn and D.J. Bottjer, Restriction of Late Neoproterozoic biotope: Suspect-microbial structures and trace fossils at the VendianCambrian transition, Palaios 14 (1999), pp. 73-85.

Hagadorn et al., 1999 J.W. Hagadorn, F. Pflüger and D.J. Bottjer, Unexplored microbial worlds, Palaios 14 (1999), pp. 1-2. 
Harms and Fahnstock, 1965 Harms, J.C., Fahnstock, R.K., 1965. Stratification, bedforms and flow phenomena (with an example from the Rio Grande). In: Middleton, G.V. (Ed.), Primary Sedimentary Structures and their Hydrodynamic Interpretation. Soc. Econ. Paleontol. Mineral., Spec. Publ. 12, 84-115.

Knoll et al., 2004 A.H. Knoll, M.R. Walter, G. Narbonne and N. Christie-Blick, A new period for the geologic time-scale, Science 305 (2004), pp. 621-622.

Kocurek, 1996 G. Kocurek, Desert aeolian systems. In: H.G. Reading, Editor, Sedimentary environments and facies, Blackwell Scientific Publications, Oxford (1996), pp. 125-153.

Noffke et al., 2001 N. Noffke, G. Gerdes, T. Klenke and W.E. Krumbein, Microbially induced sedimentary structures-A new category within the classification of Primary Sedimentary Structures, J. Sed. Res. 71 (2001), pp. 649-656.

Noffke et al., 2002 N. Noffke, A.H. Knoll and J.P. Grotzinger, Ecology and taphonomy of microbial mats in late neoproterozoic siliciclastics: a case study from the Nama Group, Namibia, Palaios 17 (2002), pp. 1-12.

Noffke et al., 2003 N. Noffke, G. Gerdes and T. Klenke, Benthic cyanobacteria and their influence on the sedimentary dynamics of peritidal depositional systems (siliciclastic, evaporitic salty, and evaporitic carbonatic), Earth Sci. Rev. 62 (2003), pp. 163-176.

Noffke et al., 2006 N. Noffke, K.A. Eriksson, R.M. Hazen and E.L. Simpson, A new window into Early Archaean life: Microbial mat in Earth's oldest siliciclastic tidal deposits (3.2 Ga Moodies Group, South Africa), Geology 34 (2006), pp. 253-256.

Paliwal, 1998 B.S. Paliwal, Felsic volcanics interlayered with sediments of the Marwar Super group at Chhoti Khatu, District Nagour, Rajasthan, J. Geol. Soc. Ind. 52 (1998), pp. 81-86. 
Pareek, 1981 H.S. Pareek, Basin configuration and sedimentary stratigraphy of Western Rajasthan, J. Geol. Soc. Ind. 22 (1981), pp. 517-527.

Parizot et al., 2005 M. Parizot, P.G. Eriksson, T. Aifa, S. Sarkar, S. Banerjee, O. Catuneanu, W. Altermann, A.J. Bumby, E.M. Bordy, J.L. Van Rooy and A.J. Boshoff, Suspected microbial mat-related crack-like sedimentary structures in the Palaeoproterozoic Magaliesberg Formation sandstones, South Africa, Precambrian Res. 138 (2005), pp. 274-296.

Pflüger, 1999 F. Pflüger, Matground structures and redox facies, Palaios 14 (1999), pp. 25-39.

Pflüger and Gresse, 1996 F. Pflüger and P.G. Gresse, Microbial sandchips-a nonactualistic sedimentary structure, Sed. Geol. 102 (1996), pp. 263-274.

Pflüger and Sarkar, 1996 F. Pflüger and S. Sarkar, Precambrian bedding planes- bound to remains, Geol. Soc. Am. 28 (7) (1996), p. 491 (Abstract with programmes).

Rathore et al., 1996 S.S. Rathore, T.R. Venkatesan and R.K. Srivastava, Rb-Sr and ArAr systematics of Malani volcanic rocks of southwest Rajasthan: Evidence for a younger post-crystallization thermal event, Proc. Indian Acad. Sci. (Earth Planet Sci.) 105 (1996), pp. 131-141.

Rathore et al., 1998 S.S. Rathore, T.R. Venkatesan and R.K. Srivastava, Rb-Sr Isotope Dating of Neoproterozoic (Malani Group) Magmatism from Southwest Rajasthan, India: Evidence of Younger Pan-African Thermal Event by ${ }^{40} \mathrm{Ar}^{39}$ - Studies, Gond. Res. 2 (2) (1998), pp. 271-281. 
Reineck and Singh, 1980 H.E. Reineck and I.B. Singh, Depositional Sedimentary Environments: With Reference to Terrigenous Clastics, Springer-Verlag, New York (1980).

Reysenbach and Cady, 2001 A.L. Reysenbach and S.L. Cady, Microbiology of ancient and modern hydrothermal systems, Trends Microbiol. 9 (2) (2001), pp. 79-86.

Roy and Jakhar, 2002 A.B. Roy and S.R. Jakhar, Geology of Rajasthan (Northwest India) Precambrian to Recent, Scientific Publishers, India (2002) p. 421.

Sarkar et al., 2004 S. Sarkar, S. Banerjee and P.G. Eriksson, Microbial mat features in sandstones illustrated. In: P.G. Eriksson, W. Altermann, D.R. Nelson, W.U. Mueller and O. Catuneanu, Editors, The Precambrian Earth: Tempos and Events, Elsevier, Amsterdam (2004), pp. 673-675.

Sarkar et al., 2005 S. Sarkar, S. Banerjee, P.G. Eriksson and O. Catuneanu, Microbial mat control on siliciclastic Precambrian sequence stratigraphic architecture: examples from India, Sed. Geol. 176 (2005), pp. 195-209.

Sarkar et al., 2006 S. Sarkar, S. Banerjee, P. Samanta and S. Jeevankumar, Micrbial matinduced sedimentary structures in siliciclastic sediments: examples from the $1.6 \mathrm{Ga}$ Chorhat Sandstone, Vindhyan Supergroup, M.P., India, J. Earth Syst. Sci. 115 (1) (2006), pp. 49-60.

Schopf, 1999 J.W. Schopf, Cradle of Life. The Discovery of Earth's Earliest Fossils, Princeton University Press, Princeton, New Jersey (1999) p. 367.

Schieber, 1998 J. Schieber, Possible indicators of microbial mat deposit in shale and sandstones: example from the Mid- Proterozoic Belt Supergroup, Montana, USA, Sed. Geol. 120 (1998), pp. 105-124. 
Schieber, 1999 J. Schieber, Microbial mats in terrigenous clastics: The challenge of identification in the rock record, Palaios 14 (1999), pp. 3-12.

Schieber, 2004 J. Schieber, Microbial mats in the siliciclastic rock record: a summary of the diagnostic features. In: P.G. Eriksson, W. Altermann, D.R. Nelson, W.U. Mueller and O. Catuneanu, Editors, The Precambrian Earth: Tempos and Events, Elsevier, Amsterdam (2004), pp. 663-673.

Schieber et al., 2007 J. Schieber, P.K. Bose, P.G. Eriksson, S. Banerjee, S. Sarkar, W. Altermann and O. Catuneanu, Atlas of microbial mat features preserved within the Siliciclastic rock record. Atlases in Geoscience 2, Elsevier, Amsterdam (2007) 311pp..

Seilacher, 1991 A. Seilacher, Self-organizing mechanisms in morphogenesis and evolution. In: N. Schmidt-Kittler and K. Vogel, Editors, Constructional Morphology and Evolution, Springer, Berlin (1991), pp. 51-271.

Seilacher and Pflüger, 1994 A. Seilacher and F. Pflüger, From biomats to benthic agriculture: a biohistoric evolution. In: W.E. Krumbein, D.M. Paterson and L.J. Stal, Editors, Biostabilization of Sediments. Bibliotheks and Informationssystems der Carl von Ossietzky Universit,, St Oldenburg (BIS), Oldenburg, Germany (1994), pp. 97-105.

Simonson and Carney, 1999 B.M. Simonson and K.E. Carney, Roll-up structures: evidence of insitu microbial mats in Late Archaean Deep Shelf Environments, Palaios 14 (1999), pp. 13-24.

Westall et al., 2003 F. Westall, M.M. Walsh, J. Toporski and A. Steele, Fossil Biofilm and the search for life on Mars. In: W.E. Krumbein, D.M. Paterson and G.A. Zavarain, Editors, Fossil and Recent Biofilms, Kluwer Academic Publishers, Netherlands (2003), pp. 447-465. 